BLS 32, No 2 2006. DOI: http://dx.doi.org/10.3765/bls.v32i2.3491

(published by the Berkeley Linguistics Society and the Linguistic Society of

America)

\title{
Reconciling meng- and NP Movement in Indonesian ${ }^{1}$
}

\author{
CATHERINE R. FORTIN \\ University of Michigan
}

\section{Introduction}

In this paper, I present a new analysis of the Indonesian 'voice marker prefix' meng-: I argue that it is not a voice marker or a prefix at all, but instead an indefinite object clitic, unspecified for person and number, which has the effect of 'antipassivizing,' the verb hosting it. To support my claim, I review restrictions on the distribution of meng-, which although previously noted (e.g. Saddy 1991, Cole and Hermon 1998), remained unexplained under previous analyses of meng-. I further suggest an incorporation analysis of meng- (Baker 1988) that accounts for these distributional restrictions.

\section{1. 'Voice' in Indonesian}

As an Austronesian language, Indonesian has traditionally been analyzed as having a system of voice-related morphology, albeit one somewhat less elaborate than that of Malagasy or Tagalog. Hence, meng- is typically considered to be an active voice marker (1)-(2), ${ }^{3}$ by analogy with the passive voice marker $d i$ - (3).

$$
\begin{aligned}
& \text { Ali menulis/tulis surat ini. } \\
& \text { Ali meng-write/write letter this } \\
& \text { 'Ali wrote this letter.' }
\end{aligned}
$$

\footnotetext{
${ }^{1}$ I am indebted to my language consultants Kathy Triyana, Jingga Morry, and Nancy Surachman. For extremely helpful discussion about the ideas presented here, I am grateful to Acrisio Pires, Daniel Seely, Sam Epstein, and audiences at the Michigan Linguistic Society's 2005 meeting (at Michigan State University) and at BLS 32, especially Mark Donohue. Any errors are my sole responsibility.

${ }^{2}$ Aldridge (2006) also suggests that Indonesian verbs marked with meng- are a remnant of ergativity in Indonesian, although the details of her analysis differ from the one presented here.

${ }^{3}$ The details and notation of this assumption vary. For Sneddon (1996) and Voskuil (2000), mengsimply marks active voice; for, e.g., Chung (1976), meng- marks transitivity or agentivity; for Postman (2002), meng- bears a [+active] feature; for Englebretson (2003), meng- indicates 'agent trigger'. Under some analyses, meng- is not merely a marker, but a morpheme that has the function of Case-marking the direct object (e.g. Guilfoyle, Hung, and Travis 1992; Son and Cole 2004).
} 
(2) Ali mengira Hasan mengharap Dani mencintai Andi. Ali meng-think Hasan meng-expect Dani meng-love Andi 'Ali thinks that Hasan expects that Dani loves Andi.'

$\begin{array}{lll}\text { Surat ini } \quad \text { ditulis/*tulis } & \text { (oleh) Ali. } \\ \text { letter this } \quad \text { PASS-write/*write } & \text { (by) Ali } \\ \text { 'This letter was written by Ali.' } & & \end{array}$

Descriptively speaking, meng- and $d i$ - behave similarly. They appear only on semantically transitive verbs (i.e. verbs that assign theta roles to both an external and internal argument) and never on semantically intransitive verbs (i.e. verbs that only have one theta role to assign to an argument), e.g. (4). ${ }^{4}$

$$
\begin{aligned}
& \text { Ali sedang tidur/*menidur/*ditidur. } \\
& \text { Ali PROG sleep/*meng-sleep/*PASS-sleep } \\
& \text { 'Ali is sleeping.' }
\end{aligned}
$$

The presence of meng- correlates with an agent-to-subject mapping (1), and the presence of $d i$ - correlates with a patient-to-subject mapping (3). However, meng- and $d i$ - differ in one (arguably crucial) respect: meng- is optional (1), while $d i$ - is not. Although not all passive clauses contain $d i$-, the word order of a passive without $d i$ - (a 'bare passive') has a different word order (5) than the di-passive (3).

$$
\begin{aligned}
& \text { Surat ini Ali tulis/*ditulis. } \\
& \text { letter DEM Ali } \quad \text { write/*PASS-write } \\
& \text { 'This letter was written by Ali.' }
\end{aligned}
$$

Furthermore, meng- has several restrictions on its distribution that are difficult to explain under the assumption that meng- is simply a voice marker. As previously noted by, e.g., Saddy (1991) and Cole and Hermon (1998), meng- cannot appear in a clause within which a complement to the verb has been extracted. Descriptively, this has been characterized as movement of a wh-NP over a verb marked with meng- forcing the 'deletion' of meng- (Cole and Hermon 1998). In sum, meng- is unable to appear in its usual environment (on semantically transitive verbs) in case of overt successive-cyclic NP movement 'over' the verb.

Contexts in which meng- is prohibited include bare passives (6).

\footnotetext{
${ }^{4}$ There is a homophonous derivational morpheme, meng-, which is used in the formation of certain denominal and deadjectival verbs (i). However, the derivational meng- behaves differently and has a different distribution from the meng- that is the focus of the current paper, so it will be set aside here.
}

(i)

$$
\begin{array}{lll}
\text { Adiknya } & \text { sedang } & \text { menangis/*tangis. } \\
\text { child-3SG } & \text { PROG } & \text { meng-cry/*cry } \\
\text { 'His/her child is crying.' } &
\end{array}
$$




\section{Reconciling meng- and NP Movement in Indonesian}

Buku ini saya $\quad\left({ }^{*}\right.$ mem $)$ baca.
book DEM 1sG
'I read that book.'

Second, meng- is also prohibited in object relative clauses (7a). Note that mengappears in subject relative clauses (7b), as there has been no operator movement 'over' the verb within the relative clause.
a. Buku yang Ali (*mem)baca itu menarik. book that Ali (*meng-)read DEM interesting 'The book that Ali read is interesting.'
b. Laki-laki yang membaca buku itu adik saya. man that meng-read book DEM sibling 1SG 'The man that's reading a book is my younger brother.'

Third, meng- is prohibited in wh-questions within which a wh-NP has moved overtly over the verb, whether the $w h$-NP is the embedded clause object (8) or the embedded clause subject (9). Note that in (9), as the wh-NP has moved only 'over' the matrix verb harapkan 'hope', meng- can appear on the embedded verb beli 'buy'.

$$
\begin{aligned}
& \text { Apa }_{\mathrm{i}} \text { yang kamu (*meng)harapkan [cP } \mathrm{t}_{\mathrm{i}} \text { Ali akan }\left(* \text { mem)beli } \mathrm{t}_{\mathrm{i}}\right. \text { ? } \\
& \text { what that 2SG (*meng-)hope Ali FUT }\left({ }^{*}\right. \text { meng-)buy } \\
& \text { 'What do you hope Ali will buy?' }
\end{aligned}
$$

(9) Siapa $a_{i}$ yang kamu (*meng)harapkan $\left[{ }_{C P} t_{i} t_{i}\right.$ akan membeli mobil ini? who that 2SG (meng-)hope FUT meng-buy car DEM 'Who do you hope will buy this car?'

In addition to $w h$-movement to the matrix [Spec, $\mathrm{CP}$ ], Indonesian also allows $w h$ in-situ and partial wh-movement to an intermediate [Spec, CP] (10). In partial movement contexts, meng- can appear on verbs above the landing site of the whNP. In $w h$-in-situ contexts, meng- can appear on any verb in the sentence, indicating that it is only overt NP movement that is incompatible with the presence of meng- on a verb (as argued by Cole and Hermon 1998).

$$
\begin{aligned}
& \text { Kamu mengharapkan [CP apa } \mathrm{C}_{\mathrm{i}} \text { yang Ali akan }\left({ }^{*} \text { mem)beli } \mathrm{t}_{\mathrm{i}}\right. \text { ? } \\
& \text { 2SG meng-hope what } \\
& \text { 'What do you hope Ali will buy?' }
\end{aligned}
$$

The appearance of meng- on a verb is not incompatible with other types of whmovement over it. Movement of a $w h$-adverbial (11) over a verb does not prohibit its bearing meng-, nor does the movement of a wh-PP (12). (12) also illustrates 
that the incompatibility of meng- with wh-movement is not the result of an argument/adjunct distinction, but is instead the result of an NP/other kinds of XP distinction (as noted by Cole and Hermon 1998).

(11) Mengapa $a_{i}$ kamu mengharapkan [CP $t_{i}$ Ali akan membeli mobil $t_{i}$ ? why 2SG meng-hope Ali FUT meng-buy car 'Why do you hope Ali will buy a car?'

(12) Kepada siapa $a_{i}$ kamu mengharapkan [ ${ }_{\mathrm{CP}} \mathrm{t}_{\mathrm{i}}$ Ali akan memberi mobilnya $\mathrm{t}_{\mathrm{i}}$ ? to who 2SG meng-hope Ali FUT meng-give car-3SG 'To whom do you hope Ali will give his car?'

In sum, previous analyses of meng- as a 'voice', 'agentivity', or 'transitivity' marker leave several important questions unanswered. Why must such a marker be incompatible with wh-NP movement 'over' the verb hosting it, but not be troubled by movement of a $w h$-PP or a $w h$-adverbial?

In addition, if, as I have argued, meng- is not a voice marker, what kind of verbal prefix could it be? It is seemingly not a derivational morpheme, as the presence of meng- in an active clause contributes nothing to the meaning of the clause or the verb that bears it, as evidenced by its optionality in these contexts. It is likewise seemingly not an inflectional morpheme: meng- does not reflect agreement, tense, aspect, mood, person, number, or any of the categories typically associated with inflection (and which are accounted for within the structure of the clause motivated in Chomsky 1995, the syntactic framework adopted here). Finally, the behavior of meng- is unique in the set of Indonesian verbal prefixes (the others are di-; ter-, which is the involuntary/stative/abilitative marker; and bar-, which marks certain semantically intransitive verbs); only meng- is optional.

In the remainder of this paper, I will argue for a novel analysis of meng- that capitalizes upon its somewhat restrictive distribution. I suggest that the appropriate way to characterize the absence of meng- in such contexts is not that meng- is 'deleted' as the result of successive-cyclic NP movement over it, but instead that meng- has the effect of blocking successive-cyclic NP movement over it. ${ }^{5} \mathrm{I}$ argue that the ability of meng- to block NP movement can be accounted for under an analysis of meng-as a theta-marked object clitic pronoun.

\section{2. meng- Is a Clitic Pronoun}

\subsection{When meng- Is Mandatory}

In the previous section, I described contexts where meng- is prohibited from appearing in its customary environment and noted that meng- is otherwise optional in the context in which is it is licensed: clauses containing a semantically

\footnotetext{
${ }^{5}$ An additional problem with characterizing the absence of meng- in these contexts as 'deletion' arises: within the Minimalist Program, it is not clear what it means to say that part of a word must delete, or how such a deletion could be implemented, given standard theories of ellipsis.
} 
transitive verb with an agent-to-subject mapping. However, there are certain semantically transitive verbs that do not require the internal object to be overtly expressed (13a); in such contexts, meng- becomes mandatory (13b).
a. Ali sedang membaca (buku itu).
Ali PROG meng-read (book DEM)
'Ali is reading (that book).'
b. * Ali sedang baca.
'Ali is reading.'

The obligatoriness of meng- only in contexts where no object NP is overtly expressed will immediately follow if meng- itself is the object NP.

\subsection{The Nature of meng-}

My proposal is that meng- does not merely signal that the clause is an active voice clause: meng- further has the effect of 'antipassivizing' the verb that hosts it. This is because meng- is not simply a piece of verbal morphology, but an indefinite object clitic pronoun unmarked for person and number. In a clause containing meng- (14), meng- originates in the theta position of the internal argument and moves to adjoin to the verb ${ }^{6}$ (see, e.g., Baker 1988), as in (15). As in a true antipassive construction, in such clauses an overtly specified object NP (in this case, surat ini 'the letter') is optional.

$$
\begin{aligned}
& \text { Ali menulis (surat ini), } \\
& \text { Ali meng-write (letter DEM) } \\
& \text { 'Ali wrote (the letter).' }
\end{aligned}
$$

\footnotetext{
${ }^{6}$ Contra, e.g., Guilfoyle, Hung, and Travis (1992), I assume that V-to-T movement does not take place overtly in Indonesian. Guilfoyle, Hung, and Travis make the assumption that it does for theory-internal reasons. Although the matter needs to be investigated more thoroughly, it seems to be true that $\mathrm{V}$ does not raise in the overt syntax, as it does not raise above adverbs that are generally assumed to mark the edge of the VP, such as sering 'often', as in (i). Nothing in my proposal hangs on this assumption, however.
}
a. Dia tidak sering menulis surat. 3SG NEG often meng-write letter 'He/she doesn't often write letters.' b. * Dia tidak menulis sering surat. 
Catherine R. Fortin

(15)

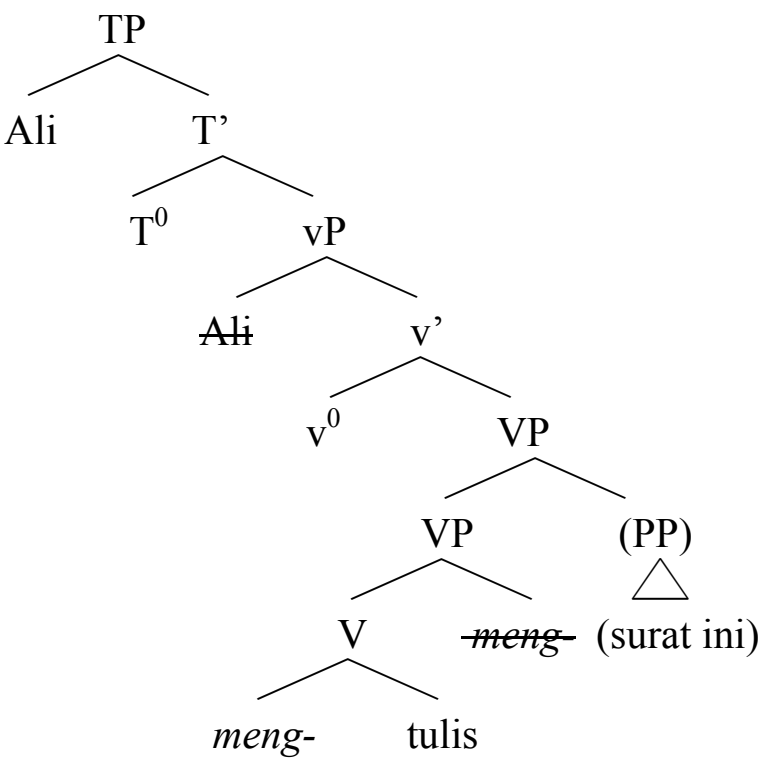

In a clause without meng- (16), the object NP merges into the theta position of the internal argument. That meng- is mandatory when the clause contains no overtly expressed object NP follows: meng- in this case is required by the Theta Criterion, so that the verb's internal theta role is assigned. If this proposal is on the right track, there are no 'optionally transitive' verbs in Indonesian; in every case, the verb's internal theta role is assigned to some element, either meng- (if it is present) or a lexical NP.

$$
\begin{aligned}
& \text { Ali tulis surat ini. } \\
& \text { Ali write letter } \\
& \text { 'Ali wrote the letter.' }
\end{aligned}
$$

This analysis of meng- accounts for the prohibition of meng- on semantically intransitive verbs. If the verb has no internal theta role to assign to meng-, a violation of the Theta Criterion will result. Conversely, if the semantically intransitive verb has only an internal theta role to assign, the possibility of it being assigned to meng-is ruled out by its function: as in a true antipassive construction, the antipassivizing morpheme can never represent the only argument of a verb (as noted by, e.g., Baker 1988).

If both meng- and an overtly expressed object NP appear in the clause (as in (1)), only meng- originates in the theta position of the internal argument. The overtly expressed object NP is then a VP adjunct coreferential with meng-, such that the reference of meng- is determined by the adjunct NP (see, e.g., Baker 1988). Again, as in a true antipassive construction, if no object NP is overtly expressed, the object is interpreted as being indefinite, unknown, or unspecified. I assume that Case on the adjunct NP is checked by a null preposition, akin to the null preposition that checks the Case of the agent NP in $d i$-passives (17). (In by- 


\section{Reconciling meng- and NP Movement in Indonesian}

phrases of $d i$-passives, an overt preposition, oleh 'by', is optional.) As Indonesian displays no morphological case distinctions, oblique or otherwise, it is unsurprising that an 'object' NP in a meng-ful clause bears no morphological case marking to distinguish it from a true object NP in a meng-less clause.

$\begin{array}{lllll}\text { Piring itu sudah dicuci } & \text { oleh/ } \varnothing & \text { Pak Ali. } \\ \text { dish DEM already } & d i \text {-wash by } & \text { Mister Ali } \\ \text { 'These dishes } & \text { were already washed by Pak Ali.' }\end{array}$

'Passive' by-phrases containing the null preposition are prohibited from whextracting in the same way that the adjunct NP in a clause containing meng- is (18b), although $w h$-in-situ is available (18a). As noted above, it is possible to extract a $w h-\mathrm{PP}$, as in (18c). There is something unique, then, with respect to the null prepositions found in passive by-phrases and in adjunct NPs in clauses containing meng-. ${ }^{7}$
a. Ali dipukul
(oleh) siapa?
Ali PASS-hit
(by) who?
b. * Siapa Ali dipukul (oleh)? who Ali PASS-hit (by)
c. Oleh siapa Ali dipukul?

by who Ali PASS-hit

'Who hit Ali?'

\subsection{Why meng- and NP Movement Are Incompatible}

If, as I have argued, meng- is the object NP in a meng-ful clause, and overt 'object' NPs in such clauses are in actuality adjuncts, we can easily explain why the presence of meng- in a clause disallows the possibility of extraction from the (apparent) complement, as in bare passives, object relative clauses, and whquestions.

As noted above, in bare passives (19), meng- is prohibited.

\footnotetext{
${ }^{7}$ Mark Donohue (p.c.) has suggested that the ban on movement of the null preposition-headed passive $b y$-phrase could be the result of the null preposition 'incorporating' into the verb. In Indonesian, wh-movement which strands the preposition is not possible (18b); the preposition must be pied-piped along with the $w h$-element (18c). Additionally, there is a strict adjacency requirement between the verb and a null preposition-headed by-phrase, although there is no such requirement for an oleh-headed $b y$-phrase (i). For a more detailed analysis, please see Fortin (in preparation).
}

$$
\begin{array}{llccc}
\text { Ali } & \text { dipecat } & \text { kemarin } & *(\text { oleh }) & \text { bosnya. } \\
\text { Ali } & \text { PASS-fire } & \text { yesterday } & \text { (by) } & \text { bos-3SG } \\
\text { 'Ali was fired yesterday by his boss.' } & &
\end{array}
$$




\section{Catherine R. Fortin}

(19)
Buku itu saya (*mem)baca.
book DEM 1SG (*meng-)read
'I read the book.'

If meng- is present in the clause, meng-is first merged into the theta position of the object, while buku itu 'the book' is a VP adjunct (20a). Adjuncts are prohibited from raising to an A-position by the Chain Condition (Chomsky 1986). As an illustration, I will assume a canonical passive clause structure for Indonesian bare passives, similar in relevant respects to that proposed for Indonesian by Guilfoyle, Hung, and Travis (1992). Independently, Son and Cole (2004) have argued that Indonesian $\mathrm{T}^{0}$ has an EPP feature which must be satisfied by an NP in its specifier position in the overt syntax; for this reason, I assume that buku itu is indeed in $\left[\right.$ Spec, $\left.\mathrm{T}^{0}\right]$ in $(20 \mathrm{~b}){ }^{8}$

(20)

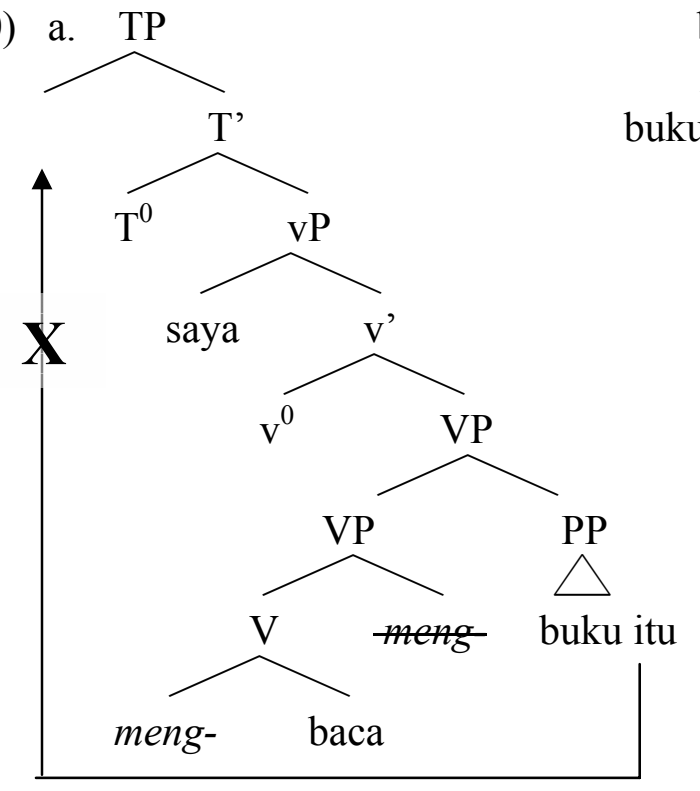

b. TP
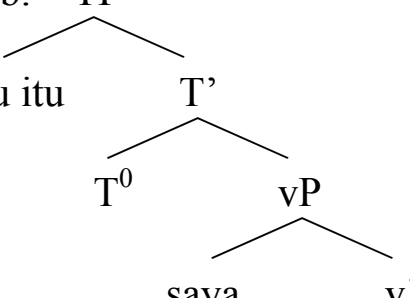

saya
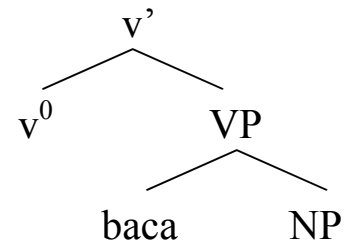

buku itu

Finally, in $w h$-questions where a $w h$-NP has moved overtly over a verb, mengon that verb is prohibited. This is true of both monoclausal wh-questions (21b) and multiclausal $w h$-questions where a $w h$-NP originating in an embedded clause raises to a position in a higher clause (22b). In both kinds of questions, wh-in-situ does not prevent meng- from appearing (21a), (22a).

$$
\begin{array}{lll}
\text { a. Kamu membeli apa? } & \text { apa } \\
\text { 2SG (meng-)buy } & \text { what } \\
\text { 'What did you buy?' } &
\end{array}
$$

\footnotetext{
${ }^{8}$ For a more complete analysis of Indonesian clause structure, please see Fortin (in preparation).
} 
b. Apa $\mathrm{i}_{\mathrm{i}}$ yang kamu (*mem)beli $\mathrm{t}_{\mathrm{i}}$ ? what that 2SG (meng-)buy

'What did you buy?'

a. Kamu mengiharapkan [cP Ali akan membeli apa $]_{i}$ ? 2SG meng-hope Ali FUT meng-buy what 'What do you hope that Ali will buy?'

b. Apa $a_{j}$ yang kamu (*meng $\left.{ }_{i}\right)$ harapkan $\left[\mathrm{CP} \text { Ali akan }\left({ }^{*} \text { mem }_{\mathrm{j}}\right) \text { beli } \mathrm{t}_{\mathrm{j}}\right]_{\mathrm{i}}$ ? what that 2SG (*meng-)hope Ali FUT (*meng-)buy 'What do you hope Ali will buy?'

In both monoclausal and multiclausal wh-questions, meng- first merges into the theta position of the internal argument of the verb. In the monoclausal question, the wh-word apa 'what' is a VP adjunct that is coreferent with meng- (23a); only if meng- is not present will apa be merged into an A-position, as the complement to the verb (23b). In the multiclausal question, the entire embedded $\mathrm{CP}$ Ali akan beli apa 'Ali will buy what' is an adjunct to the matrix VP (not shown). In both cases, extraction of apa from the adjunct to the matrix TP position (again, to satisfy the matrix $\mathrm{T}^{0}$ s $\mathrm{s}$ EP feature) is prohibited because it induces an island violation.

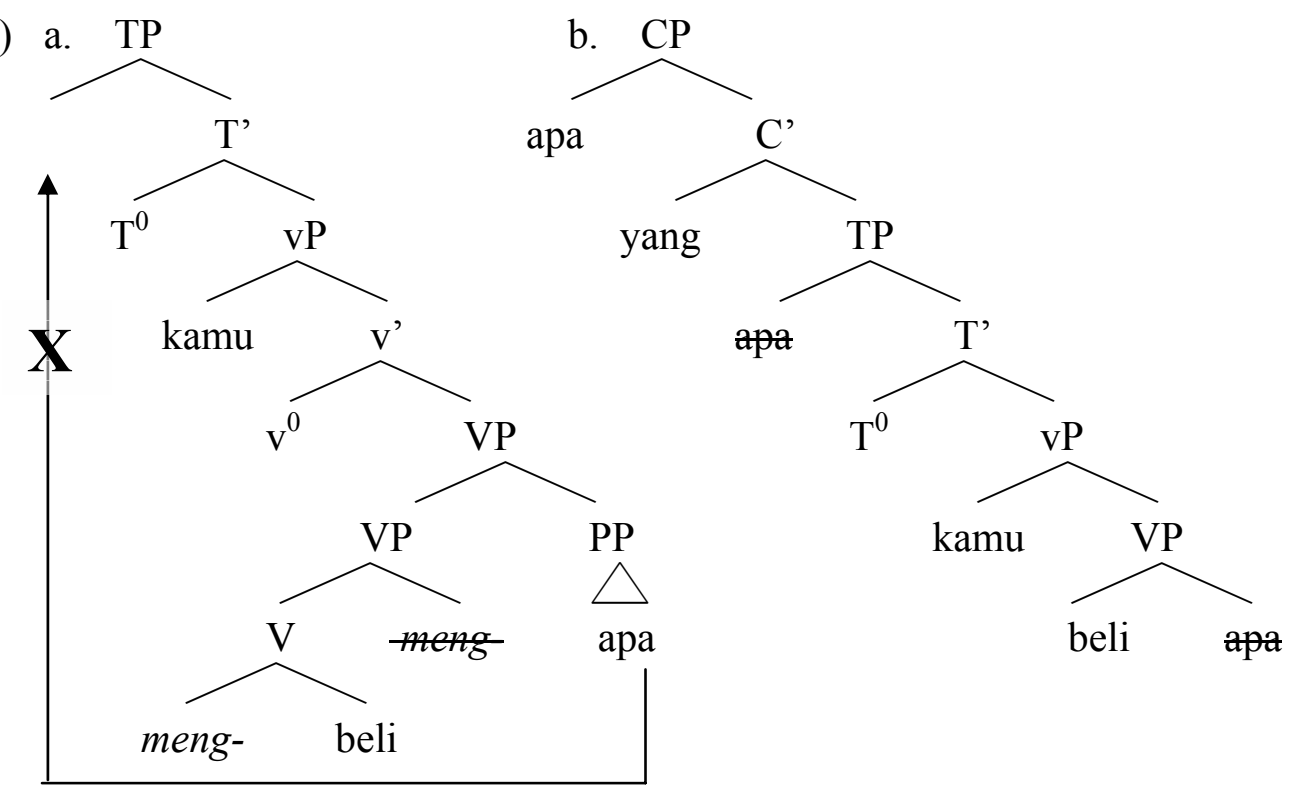

Cole and Hermon (1998) illustrate that extraction from an adjunct yields island effects in Singaporean Malay, and this is likewise true for the variety of Indonesian described in the present paper. As (24b) shows, extraction of apa from an adjunct (the clause headed by karena 'because') is prohibited, although leaving 


\section{Catherine R. Fortin}

apa in situ does not result in an island violation (24a).
a. Ali dipecat
karena dia beli apa?
Ali PASS-fire because 3SG bought what
'Ali was fired because he bought what?'
b. * Apa yang Ali dipecat karena dia beli $t_{i}$ ? what that Ali PASS-fire because 3SG buy
'What was Ali fired because he bought?'

For similar reasons, meng- is prohibited in object relative clauses (25).

$$
\begin{aligned}
& \text { Buku yang Ali (*mem)baca itu menarik. } \\
& \text { book that Ali (meng-)read this interesting } \\
& \text { 'The book that Ali read is interesting.' }
\end{aligned}
$$

For purposes of illustration, I will assume here a standard analysis of relative clauses for Indonesian (but see fn 8). If meng- is present in the relative clause, it is again first merged into the theta position of the object (for space limitations, this is not shown graphically). If this is the case, the relative clause operator cannot be merged into this position, but is instead an adjunct to the VP. The operator cannot extract from the adjunct to [Spec, $\mathrm{CP}$ ] of the relative clause, which prevents the proper binding relationship between the operator and the variable from being established; as noted above, extraction from an adjunct in Indonesian gives rise to island effects and is thus prohibited. If meng- is not present in the relative, the operator is merged into the theta position and is able to extract to [Spec, $\mathrm{CP}]$, establishing the binding relationship between the operator and the variable.

\section{Conclusion}

In this paper, I have argued that Indonesian meng- is not simply a marker which signals active voice, agentivity, or transitivity, as is generally assumed (for references, see fn 3). Instead, I have argued that meng- is an indefinite object clitic pronoun that is unspecified for person and number. As meng- is first merged into the theta position of the verb's internal argument, meng- has the effect of 'antipassivizing' the verb that hosts it. If there is an overt 'object' NP in the clause, the reference of meng-is determined by this NP, with which meng-is co-indexed. If meng- is present, however, an overt 'object' is not necessary; in this case, the object is interpreted as being indefinite, unknown, or unspecified, as in a 'true' antipassive.

Since meng- is merged into the theta position for the internal argument, an overt 'object' NP in the clause is in actuality a VP adjunct. The analysis of mengsuggested in the present paper uniquely accounts for the restrictions on the distribution of meng- in certain contexts: namely, meng- is prohibited from appearing in any clause within which the object NP has moved, such as bare 
passives, object relative clauses, and wh-questions within which a wh-NP has moved 'over' the verb. This restriction on the appearance of meng- is not easily explained in an analysis where meng- simply marks agentivity or transitivity. In the present analysis, however, this restriction is easily accounted for: if meng- is present in the clause, any 'object' NP is actually an adjunct, and NP movement from out of the adjunct is prohibited. In the case of bare passives, NP movement from the adjunct to [Spec, T], an A-position, is ruled out by the Chain Condition. In the case of wh-movement and object relative clauses, island effects prohibit movement of (or from within) the adjunct $w h$-NP or the operator.

This analysis further accounts for the fact that meng- is optional in all environments in which it is licensed except for one: in case no object NP is overtly expressed. If this analysis is on the right track, it implies that no Indonesian verbs are 'optionally' transitive: in all cases, a transitive verb assigns its internal theta role to some element, either meng- or a lexical NP. If neither meng- nor a lexical NP are present to receive the internal theta role, a Theta Criterion violation results. Likewise, the fact that the presence of meng- reflects a semantic, not syntactic, transitivity is accounted for: meng- only appears on verbs that have an internal theta role to assign to it. As in a 'true' antipassive, meng-cannot represent the only argument of an unaccusative verb, which accounts for the fact that unaccusative verbs cannot host meng-.

\section{References}

Aldridge, Edith. 2006. Phase-Based Account of Extraction in Indonesian. Paper presented at ISMIL 10, University of Delaware, Newark.

Baker, Mark. 1988. Incorporation: A Theory of Grammatical Function Changing. Chicago: University of Chicago Press.

Chomsky, Noam. 1986. Barriers. Cambridge: MIT Press.

Chomsky, Noam. 1995. The Minimalist Program. Cambridge: MIT Press.

Chung, Sandra. 1976. On the Subject of Two Passives in Indonesian. In Charles Li, ed., Subject and Topic, 57-99. New York: Academic Press.

Cole, P., and G. Hermon. 1998. The Typology of Wh-Movement: Wh-Questions in Malay. Syntax 1:221-258.

Englebretson, Robert. 2003. Searching for Structure: The Problem of Complementation in Colloquial Indonesian Conversation. Amsterdam: John Benjamins.

Fortin, Catherine. In preparation. Indonesian Ellipsis: A Descriptive and PhaseBased Minimalist Analysis. Ph.D. diss., University of Michigan.

Guilfoyle, E., H. Hung, and L. Travis. 1992. Spec of IP and Spec of VP: Two Subjects in Austronesian Languages. Natural Language and Linguistic Theory 10:375-414.

Postman, Whitney Anne. 2002. Thematic Role Assignment in Indonesian: A Case Study of Agrammatic Aphasia. Ph.D. diss., Cornell University. 
Saddy, Douglas. 1991. Wh-Scope Mechanisms in Bahasa Indonesia. More Papers on Wh-Movement: MIT Working Papers 15:183-218.

Son, M., and P. Cole. 2004. Interface between Event Semantics and Syntax with Special Reference to the Verbal Suffix -kan in Standard Indonesian. Paper presented at GURT 2004, Georgetown University, Washington, DC.

Sneddon, James Neil. 1996. Indonesian: A Comprehensive Grammar. London: Routledge.

Voskuil, Jan E. 2000. Indonesian Voice and A-Bar Movement. In I. Paul, V. Phillips, and L. Travis, eds., Formal Issues in Austronesian Linguistics, 195-213. Dordrecht: Kluwer.

Catherine R. Fortin

Department of Linguistics

University of Michigan

1190 Undergraduate Science Building

204 Washtenaw Avenue

Ann Arbor, MI 48109-2215

fortinc@umich.edu 